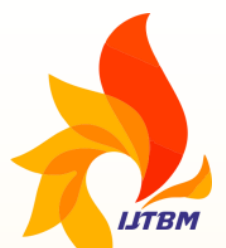

INTERNATIONAL JOURNAL OF

TRANSFORMATIONS IN BUSINESS MANAGEMENT

e-ISSN: 2231-6868, p-ISSN:2454-468X

\title{
THE ROLE OF VISUAL REPRESENTATION IN ENHANCING THE QUALITY OF PROGRESS REPORTS
}

Asst Prof Emad Ghafoori Abood AL Najjar

Lecturer Sajjad Mahdi Abbas

Wasit University, Iraq

Paper Received: 05 ${ }^{\text {th }}$ December, 2021; Paper Accepted: $30^{\text {th }}$ December 2021;

Paper Published: $11^{\text {th }}$ January, 2022

DOI: http://doi.org/10.37648/ijtbm.v12i01.002

How to cite the article:

Emad Ghafoori Abood AL Najjar, Sajjad Mahdi Abbas, The Role of

Visual Representation in Enhancing

The Quality of Progress Reports,

IJTBM, January-March 2022, Vol

12, Issue 1; 31-52, DOI:

http://doi.org/10.37648/ijtbm.v12i01.

002
$-15 S N$ : 2231-6868 p-15SN : 2454-468X

International Journal of Transformation in

\section{Business} Management

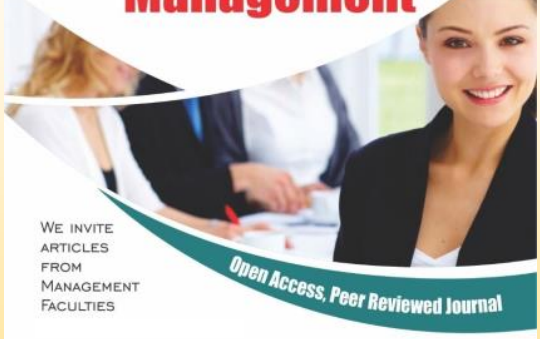

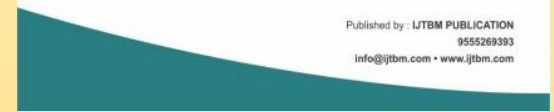




\begin{abstract}
The financial reporting function represents one of the workshops of the development of accounting and accounting functions as it represents an extension of the efforts of academics and professionals over time and at the same time is a response to the renewed needs of users of accounting information, and that progress reporting represents an integrated entry point of financial reporting, it is in line with the objectives of the conceptual framework for financial accounting, which is to provide appropriate and honest ly-represented information, and that enhancing the quality of these reports through visual representation of information is an objective to be implemented by information providers and accountants, so the objectives of this research are the most important objectives of this research. Is to determine the most important means of visual representation of the data and its impact on the quality of the progress reporting and the research concluded that the means of visual representation affect the quality of the progress reports so the researchers recommend the adoption of these methods by the management of the company sample research.
\end{abstract}

\section{INTRODUCTION}

Policies related to the opening up of financial markets and the trend towards globalisation in recent years have resulted in the attention of shareholders and other stakeholders in the listed joint stock companies with the information that these companies should disclose, particularly the interim financial reports that ensure their preparation from joint stock companies, particularly those listed on the stock market and reviewed by an independent auditor, to provide accounting information that is appropriate and reliable from shareholders and other stakeholders in the companies concerned in a timely manner.

The great development in information technology and digital imaging and its role in enhancing the ability to understand information has become one of the requirements of internationally accepted financial reporting. We find that the conceptual framework for international financial reporting focused mainly on the characteristics of information quality, the most important of which is the appropriateness of information and its honest representation. Therefore, we find that the visual representation of information contributes to making The information is appropriate and understandable, and helps in communicating and understanding it, which affects the decisions of the users, especially about the integration of these technologies with the progress reports, which are an advanced form of financial reporting models. 


\section{VOLUME: 12, ISSUE: 1, JANUARY-MARCH 2022}

\section{RESEARCH METHODOLOGY}

\section{Research Problem}

The joint stock companies issue interim financial reports for periods of time less than a full fiscal year, often quarterly or semiannual, and the main objective of these reports is to provide appropriate and timely information and the introduction of visual representation as an essential part of the information system equipped for progress reports enhances the quality of those reports and reduces the dispersion of users' thinking resulting from successive versions of those reports, so the problem of research ing the lack of progress reports of the listed companies on the Iraq Stock Exchange Financial (ISX) features visual representation, which reduces the quality of information provided by these reports and their ability to influence user decisions.

\section{Research Hypothesis:}

(The adoption of visual representation of accounting information in the preparation of progress reports enhances the quality of the information provided by those reports and thus improves their ability to influence users' decisions of such information)

Research objectives:

The research achieves a set of objectives and as follows:

A- Study the concept and importance of interim financial reports, and analyze the most prominent international criteria related to the preparation of these reports.

B- Highlighting the reality of interim financial reporting in a sample of the joint stock companies listed on the Iraqi Stock Exchange (ISX).

C- Attention to the visual representation of accounting information and an assessment of supply alternatives, with user indicators for the type of accounting information and the function of its use.

D- Development of the Iraqi stock market environment in all its components (investors, brokers and market management) through the adoption of visual representation methods in a way that works to raise the culture of users with information technologies, which is reflected in raising the efficiency of the financial market in Iraq.

\section{The Importance of Research:}

The importance of research is in two main aspects, the first aspect represents the conceptual input and the need to highlight the importance of progress financial reports in the joint stock companies with a focus on strengthening those reports with visual representation features to enhance the quality of progress reporting and at the same time enhance the efficiency of the financial market included in it, while the second aspect represents the application input which aims to analyze the reality of the progress reporting of the joint stock companies in 


\section{VOLUME: 12, ISSUE: 1, JANUARY-MARCH 2022}

terms of the quality of these reports and their appropriateness and honest representation of information and the extent to which visual representation is used as supporting means of understanding. and the ability to connect and perceive that information.

\section{Study Community}

The study seeks to test a specific hypothesis related to the evaluation of the level of interim financial reports and the extent to which visual representation sought to enhance the quality of those reports and the information confirmed in them in the listed joint stock companies (ISX) and to identify appropriate areas of development.

\section{Research Methodology:}

The following theoretical and applied research approaches were adopted in the light of the research problem and its hypotheses:

1. Theoretical aspect of research: adopting the descriptive theoretical approach to research variables and its relationships through the use of different theoretical sources of books and specialized scientific journals.

2. The applied aspect of research: adopting the method of experimental applied study in testing research hypotheses and reaching its results through the study and analysis of the interim financial reports of a sample of the joint stock companies listed on the Iraqi Stock Exchange.

\section{Previous Studies}

The study (Ajayi 2005) aimed to neutralize the ability of visual representation of information to create effective and useful information for decision-making and the researcher integrated the visual representation of information and data processing systems through the adoption of the Model XBRL model and language of financial reporting, which is the most important component of the visual representation of information and the researcher concluded that visual representation of information represents an appropriate development of financial reporting and through XBRL the accountant can provide financial and non-financial information interactive to enhance the effectiveness of decision-making.

The study (Dilla and et all, 2010) aimed to outline the uses of interactive data visualization models by many companies to provide accounting information to external users on investor spoofing sites and internal users in applications such as enterprise resource planning, balanced scorecard, network security and fraud detection systems. The researchers developed a classification to examine the current state of interactive data visualization research for accounting decision-making through three 


\section{VOLUME: 12, ISSUE: 1, JANUARY-MARCH 2022}

axes: the relationship between mission characteristics and interactive data visualization techniques, the relationship between decision-maker characteristics and interactive data visualization techniques, and the impact of interactive data visualization techniques on decision processes and results. The Janvrin and et all, 2014 study aimed to demonstrate the important role of accountants today in providing decision support to senior management by helping them analyze large and complex data sets. Interactive Data Visualization (IDV), a component of visual data representation, facilitates this process by allowing users to navigate, identify and display data through an easy-to-use interface often used as a component of data analytics, and researchers find that the IDV model is a successful way to convert unregulated data into interactive information useful for decision-making and performance evaluation.

The (Khalil and et all) study aimed to develop a visualization application to analyze the financial data of the public company that may help the user to simplify and categorize the database according to their need. The application was developed using extreme programming that allows for rapid development and is able to adapt to the changing technical change or change that occurs during the development process. The researchers developed an application that can visualize the financial data supported by the filtering feature to help the user clarify the database as needed and that the application of data visualization to analyze the financial statements of the public company helps the user to understand the data and helps the user to clarify the database as needed.

The Perdana and et all 2018 study aimed to demonstrate the role that interactive data visualization (IDV) can play in meeting this need for useful information through the organization of accounting information, particularly financial reports, in models of these qualities, examining the suitability of IDV for using non-professional investors when accessing accounting information, and researchers concluded that IDV reduces the restricted investment capabilities of nonprofessional investors by providing more appropriate information, thereby reducing the cognitive effort of non-professional investors. This combination allows these investors to perform simple and multilateral investment tasks better. By integrating three relevant views of information systems (i.e. mission technology, information quality and knowledge).

The Perkhofer and et all 2018 study aimed to illustrate the work of Big Data, which provides large amounts and new forms of structured and unstructured accounting data, which requires the management of alternative data and reporting methods highlighting the generation of insights from 


\section{VOLUME: 12, ISSUE: 1, JANUARY-MARCH 2022}

new data sources, the need for different and interactive forms of visual analytics visual ization, and the researchers concluded that the lack of knowledge and experience in terms of new types of visualization and single-focus technologies can be identified as a tool depicted as the main software, While the use of multiple data sources and the gradual application of other software tools enhance the adoption capabilities of interactive technologies.

The Qin and et all 2019 study aimed to demonstrate the importance of interactive data visualization as crucial in today's datadriven business world, which has been widely used to help with decision-making that is closely linked to the core revenues of many industrial companies. However, due to the high demand for w.r.t. data processing, data volume, speed and validity, there is an emerging need for database experts to help visualize data efficiently, effectively and in response to this request, this article explores techniques that make data visualization more efficient and effective. The researchers concluded that effective data visualization approaches process data and specific visualization specifications, which then produce perceptions with the basic goal of being effective and scalable at an interactive speed, promoting effective and appropriate decisions.

\section{Interim Financial Reports Concept}

The International Accounting Standards Committee (IASC) provided a definition of interim financial reports in the text of IAS 34 as "financial reports containing either a complete or a summary set of financial information for a period of less time than the company's financial year" after the accounting standard left the order to determine how often they were submitted to the requirements of the laws and regulations of each country. (IAS NO.34, 2006, 4 )

\section{The Importance of Progress Reports}

The importance of interim financial reports stems from the characteristics of the information provided by these reports, as they are timely, predictive and reliable, thus providing the most basic and necessary features of the reports provided to users of the information (Skek, 2010, 18).

\section{Objectives of Progress Reports}

From the IASB's perspective, the objective of interim financial reports is to provide information that is useful in economic decision-making, as in annual financial information, and interim financial reports are expected to provide qualitative information on the financial situation, performance and change in the financial position of the unit (Merhi, 2006:6). The general objective is to adopt an offer or disclosure either by providing integrated financial statements or 


\section{VOLUME: 12, ISSUE: 1, JANUARY-MARCH 2022}

summary information, as indicated by the 34 progress report criterion, to provide information that demonstrates the economic unit's ability to generate expected returns to interested parties (investors and creditors, etc.) (Hamad, 2006: 664).

\section{International Standard 34 (Interim}

\section{Financial Reports):}

This standard aims to describe the minimum content of the interim financial report and describe the principles of recognition and measurement in full or condensed financial statements for a period of time, and reliable interim financial reports in a timely manner improve the ability of investors, creditors and others to understand the entity's ability to generate profits, cash flows and liquidity in order to take into account time and cost considerations and avoid repeating previously reported information, the economic unit may be asked or may choose to provide less information on dates. This criterion sets the minimum content of the progress financial report as includes summary financial statements and selected explanatory notes. (Al-Khatib, 2009: 21).

The purpose of the progress financial report is to provide an update of the latest full set of annual financial statements. Accordingly, it focuses on new activities, events and circumstances and does not repeat the information previously reported, and the interim financial report must include at a minimum the financial position list, the comprehensive income list, the cash flow list and the list of changes in property rights, and these reports are prepared for the end of the interim period (IAS 34: 2006: 3-4).

Visual representation is a theoretical input.

The Concept of Visual Representation of Information:

Visual representation of information is "a group of techniques that govern the process of perception of information by directly dealing with the sensory and mental effects of the information user in a way that enhances the comprehension and cognitive completeness that is the state of understanding accompanying the decisionmaking.", (Ware, 2013:3) The researchers believe that the mechanisms and means of visual representation of the outputs of accounting information systems contribute to drawing a clear picture, through which information users can sense the relative importance of this information, allowing them to focus on information that contributes to making rational decisions, as it directs them to hidden aspects of the information presentation, and these means are an appropriate guidance tool. To attract information users and guide them to the efforts of the economic unit accountant and his ability to provide information that enhances confidence and reduces the uncertainty associated with decision-making 


\section{VOLUME: 12, ISSUE: 1, JANUARY-MARCH 2022}

\section{Benefits of Visual Representation:}

The visual representation methods formulate a sensory mental simulation that stimulates the sensory cells in vision and then the brain, thus contributing to improving the ability to perceive focused and valuable information and to determine the relative importance of the presented information. (4-Few, 2006: 6). The visual representation means achieve the advantages of appropriate delivery that is the component for the adequate perception of the information user, so that it gives him the ability to detect fraud in the information and make him in a continuous interactive state with receiving information that stimulates his mental and sensory cells through color guides, shapes and images as well as the ability of these means to provide direct indicators to evaluate the performance of management Economic units and administration efforts to reach the optimum utilization of available resources (Keam, 2012;5-6).

Types of Visual Representation of Information:

The means of visual representation of information are varied by the diversity of visual techniques and the science of image effects and the development of information technology and can identify the main types that can be used by the accountant to develop the function of financial reporting:
A. Geometrically-Transformed Displays: he main purpose of ergonomically transformed display technologies is to transform raw data into interactive, multi-dimensional data. The engineering presentation techniques category includes techniques from exploratory statistics such as dispersion chart arrays, etc. . ( Shneiderman ,1992;5)

B- Iconic Displays: The Creative Display Technologies category is one of the developed technologies that interacts with optical sensing through symbolic conversion to the features of the symbol can identify icons may be small faces, needle icons as used in MGV and star icons, stick icons, color icons as well as single and twodimensional time series.

C- Text presentation techniques: It is a group of exploratory techniques for information that adopts the method of tables, figures and informational framing as well as the advantages of alignment and types of lines., the most important of which are the techniques of coloring texts and the choice of writing formats and types of lines and alignments, which affect the angles of the eye view and make the information more attention and called the term Interesting techniques. (Nowell and et all ,2001: 4) . The researchers believe that these techniques are the most widespread and widely used because they are available in all text presentation programs and easy to learn and quick to influence in the user of information 
and forms, drawings, statistical indicators and time series are one of the most important components of these techniques, they focus information and ignorance of interest to users and are the most commonly used among categories of accountants and closer to accounting information systems models. According to Tegarden, visual techniques are divided into three categories (Tegarden, 1999:9):

A- Scientific visual representation: The scientific visual presentation represents a virtual scientific technique according to an audit calculation based on scientific foundations that deals with the conversion of data from calculations and scientific and engineering experiments into images and forms such as air flow around the wing of the aircraft.

B- Visual representation of data/information: It is the process of visualizing behavioral metadata into expressive and understandable forms and images that represent a symmetry or metaphor for the area of the problem, such as the analysis of the investment portfolio, such as the analysis of the investment portfolio, and $\mathrm{xBRL}$ is the language of financial reporting reports as a successful example of convincing visual representation, it includes a set of dictionaries that standardize the language, terminology and acronyms of corporate financial reporting reports in order to access the international coordination of the financial reporting function as well as providing users with a full range of tables, statistics and financial indicators that enhance understanding.

D- Virtual Reality: : It is the development of a multi-dimensional visual representation that represents an expressive threedimensional simulation and facilitates understanding of the information and is simply a computer-generated 3D simulation environment performed in real time according to the user's behavior and also labeled artificial reality and virtual environment. (Clifford ,2009: 6 )

\section{Using Visible Information in Conduction:}

The two researchers present the following: The central nervous system in the human body includes a set of sensory sensors distributed between hearing, sight, taste and touch, and that the visual representation technology is directed towards the visual sensors in a way that creates an interactive image that addresses the mind in a simple way. They are because the user deals with the information and affects it according to its suitability and its ability to formulate a graphic simulation of the results of the decision based on that information and others, where he referred to the representation as "an essential tool of human understanding and has been present for a long time, it can communicate complex information and help to understand the 


\section{VOLUME: 12, ISSUE: 1, JANUARY-MARCH 2022}

complex relationships between several variables and the detection of hidden (implicit) information.

\section{THE PRACTICAL ASPECT OF} RESEARCH

Firstly: Financial statements targeted by visual representation

After looking at the companies listed on the Iraq Stock Exchange, we find it important to target the financial statements of the companies that recorded the highest trading in stocks and in different sectors and will be based mainly on the progress reports of The Baghdad Soft Drinks Company (IBSD) as it recorded the highest trading during 2019.

Secondly: Procedures for applying the visual entry to the targeted financial statements

The application of information visual methods will be mainly limited to financial position and income disclosure information only because the two disclosures are essential disclosures that show a high percentage of useful information for investors. In a way that contributes to clarifying the difference with what is originally applied in the current reports information and what is intended to demonstrate the impact of visual representation methods in drafting interactive reports.
Thirdly: Analysis of the reality of the visual entry of the progress report of the company sample research

When analyzing the level of visual representation of the list displayed, the researcher finds the following:

1- We notice that the company used specific rectangles that show the values of the components of the balance sheet in the paragraphs of the traded assets in the values of sub-amounts and then reach a final sum.

2- The standardization in the presentation of financial reports in terms of font size, standardization of terms and titles, as well as the main and sub-tabs, in a way that contributes to enhancing comparability.

3- 3- On reviewing the above financial report, we find that it serves the requirements of standardization and does not focus on the requirements of adequate disclosure, since the applied accounting system serves comprehensive goals and standardization of information to serve the goals of the planned and national economy, while the conceptual framework for financial reporting focuses on the need to provide appropriate and honest information that

4- The company did not use the language of XBRL for interactive financial reporting, which focuses first on the presentation of the interim financial report in accordance with the requirements of IFRS 1 as well as a full range of current and future financial tables, 
statistics and indicators, which are the basis for strategic decision-making by investors, which constitutes a lack of appropriateness provided by the budget report information.

Fourth : Adjust the financial center report information (table) in accordance with the requirements of visual representation:

Figure (2) Progress Report - Partial General Budget - Assets section as of 3/31-2020

\begin{tabular}{lll}
\hline the details & $\mathbf{3 1 - 1 2 - 2 0 2 0}$ & $\mathbf{3 1 - 1 2 - 2 0 1 9}$ \\
\hline Assets : & $(000$ ID) & $(000$ ID) \\
\hline $\begin{array}{l}\text { Non-current assets: } \\
\text { Buildings - machinery - equipment (at }\end{array}$ & $163,814,527$ & $160,403,403$ \\
book value) & & \\
Deferred revenue expenditures & $\mathbf{4 6 , 9 5 2 , 8 2 3}$ & $53,721,931$ \\
Projects under construction & $\mathbf{2 5 , 9 4 4 , 5 3 2}$ & $13,390,266$ \\
\hline Long-termfinancial investments & $\mathbf{4 6 , 3 7 6 , 6 4 2}$ & $46,376,642$ \\
\hline Total non-current assets & $\mathbf{2 3 6 , 7 5 8 , 2 6 0}$ & $227,561,978$ \\
\hline Current assets : & & \\
\hline Inventory (at cost) & $\mathbf{5 0 , 5 0 8 , 8 1 0}$ & $76,240,781$ \\
Account receivable & $\mathbf{1 1 , 9 3 3 , 9 0 3}$ & $18,433,878$ \\
\hline Cash & $\mathbf{1 2 1 , 4 6 5 , 4 2 8}$ & $28,050,489$ \\
\hline Total current assets & $\mathbf{1 8 3 , 9 0 8 , 1 4 3}$ & $123,125,149$ \\
\hline Total assets & $\mathbf{4 2 0 , 4 6 6 , 4 0 3}$ & $\mathbf{3 5 0 , 6 8 7 , 1 2 7}$ \\
\hline
\end{tabular}

1- Adjustment to the names of accounts to comply with the requirements of the financial reporting standard 1 , which is the addition (term non-current assets) instead of (fixed assets) and the accounting justification is related to the components of this paragraph, as the company's financial report shows the fixed assets clause as a main address and its subcomponents fixed assets, irdad expenses, long-term financial investments and which does not comply with the requirements of IFRS1, which stipulated that the address of the main paragraph is non-current assets and characterized by fixed assets as principal address and its subcomponents fixed assets, fixed assets, fixed 


\section{VOLUME: 12, ISSUE: 1, JANUARY-MARCH 2022}

expenses, long-term financial investments, which is not in accordance with the requirements of IFRS1, which stipulates that the address of the main paragraph is noncurrent assets and characterized by fixed assets. This was adopted by the two researchers in the amendment, unlike the company's published report, which in its presentation of the asset paragraph violates the requirements of IFRS 1.

2- The color shading feature-(colored surround) was used to show the main aggregates of the components of the assets in order to inform the visual sensors of the importance of these amounts and in order to attract the attention of the user of information, especially and displayed in a colored way which is in accordance with the principles of Gestalt briefing of enclosure), (six principles reached by the Kistalt School of German Psychology in 1912 whose main objective is to identify and interpret visual behavior and discover how the pattern, formula and organization are perceived in what we see) as the reader will often think The numbers within the briefing space are the main totals, while the alignment feature was used when reformulating it to show the hierarchical relationship of the asset paragraph where the user in this way can distinguish the main totals from the sub immediately even if this is the first time he has seen the financial statements, thereby enhancing the understanding of accounting information.

2_ The title of the partial financial report has been distinguished and mediated at the top of the report to give an indication of the type and importance of the report by the accountant for users, and two comparative years have been adopted in determining the amounts of the asset paragraph to allow users to make a quick comparison as well as adopting the model arrangement stipulated in the interim financial reporting standard to serve the purposes of saving Convenient decision-making information

3_ A dark color has been adopted for the numbers for the year 2020 and a light color for the amounts for the year 2019, so that the user can distinguish the values between the two years mentioned.

4_ The subtotals were distinguished from the main groups, so that the user could distinguish the components of these numbers and distinguish the most important ones of relative importance, in addition to the researchers classifying the items of the report into main items, which are current assets, non-current assets and total assets. An indication of the information user with the results of the unit's comparative activity with previous years.

\section{Fifth : Illustration design}

The researchers convert the information and figures of the interim financial reports of 


\section{VOLUME: 12, ISSUE: 1, JANUARY-MARCH 2022}

Baghdad Soft Drinks Company into financial reports represented visually according to the following:

1- Visual representation of the information of the list of profits and losses: Table 1 below shows the levels of profit and loss for the year ended 31-12-2019, which is later portrayed according to the time series model, which achieves the following visual features: A- Predictability: As well as the predictive value provided by the progress reports, the time series model offers an additional predictive value as it demonstrates the current and expected behavior of profits and this behavior represents the most important requirement of investors in the ability to recognize returns.

The future of their investments and the researchers will use two forms of the series model to represent the profits and losses of Baghdad Soft Drinks Company according to the following table:

Table 1: Levels of profits and losses according to the progress reports of Baghdad Soft Drinks

Company and amounts in thousands of dinars

\begin{tabular}{|r|r|r|r|}
\hline Profit: Q4 & Profit: Q3 & Profit: Q2 & Profit: Q1 \\
\hline 2019-12-31 & $2019-9-30$ & $2019-6-30$ & $2019-3-31$ \\
\hline $50,603,062$ & $42,985,939$ & $21,442,951$ & $\mathbf{- 8 , 3 0 0 , 9 5 9}$ \\
\hline
\end{tabular}

The profit and loss information for Baghdad Soft Drinks Company will be portrayed in two phases, the first in general and the second in a simplified degree of detail, as shown below:

Form (3) simple columns shows the levels of profits according to the company's progress reports research sample

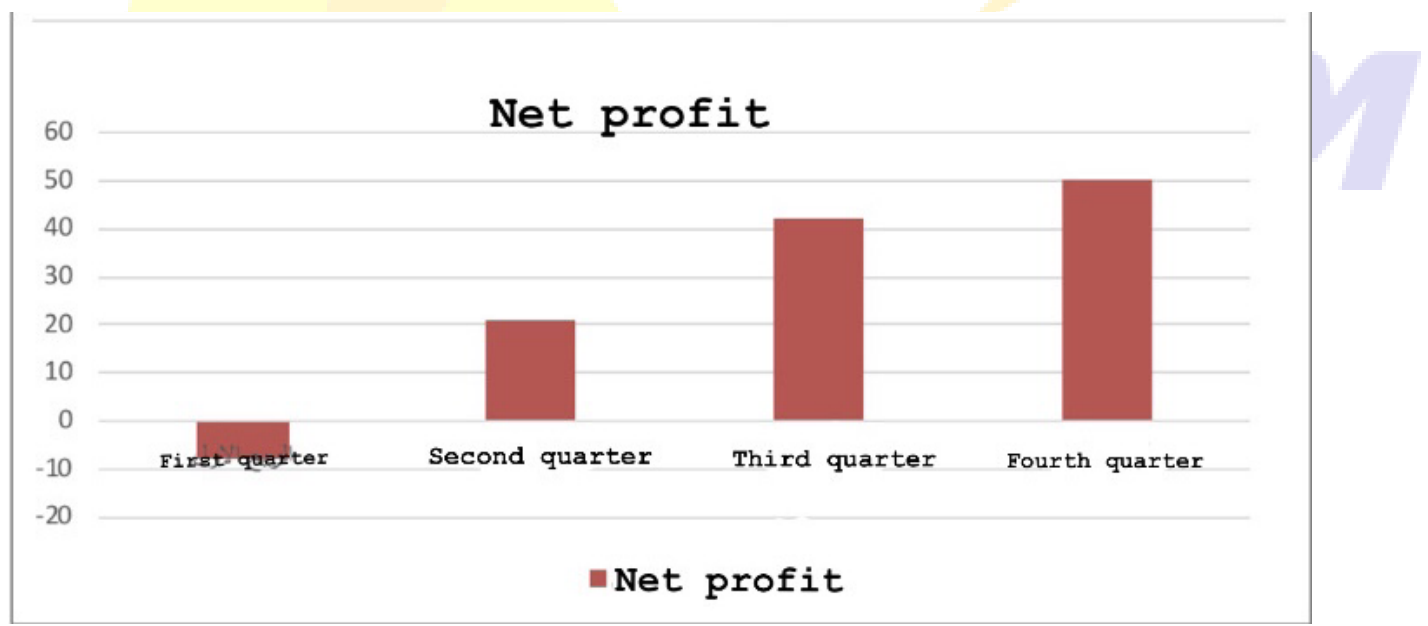




\section{VOLUME: 12, ISSUE: 1, JANUARY-MARCH 2022}

The horizontal axis of the time series (years) and vertical axis (amounts of profits and losses) was determined and then the level of profits per year is determined by the length of the column allocated for that year, and it can be said that this type of representation is the most widespread in the financial field and gives a simplified picture that enhances the understanding of progress reports and reduces the increase in information provided by the reports and can be developed by introducing more detailed variables. More financial ly so is the addition of other variables of the form, which are the analysis of the components of profits and losses to operating profits and other profits and other expenses and net total profit according to the following table:

Table (1) shows the components of the company's net profit research sample

\begin{tabular}{|c|c|c|c|c|}
\hline $\begin{array}{l}\text { Fourth quarter } \\
\text { 2019- }\end{array}$ & $\begin{array}{r}\text {-Third quarter } \\
2019\end{array}$ & $\begin{array}{r}\text { Second } \\
2019 \text {-quarter }\end{array}$ & $\begin{array}{r}\text {-First quarter } \\
2019\end{array}$ & Details \\
\hline $58,299,713$ & $48,366,011$ & $21,422,951$ & $-8,299,948$ & Operating profit \\
\hline 96,380 & 3,102 & 2,325 & 2,914 & Other profits \\
\hline $1,378,559$ & 432,786 & 348,892 & 1,900 & Other expenses \\
\hline $50,603,062$ & 42,985,939 & $21,442,951$ & $-8,300,959$ & Net profit \\
\hline
\end{tabular}

Form (1) Accumulated columns depicts the components of net profit for the research sample company

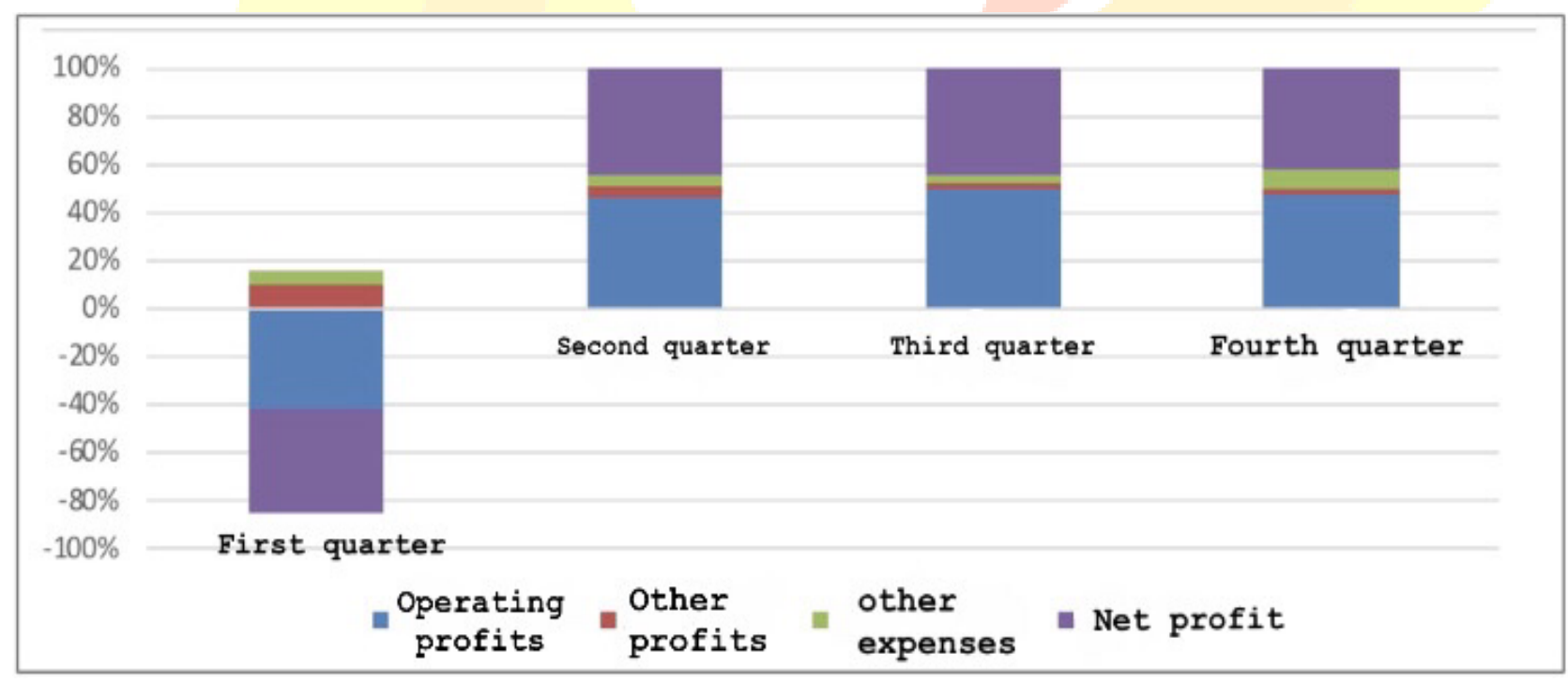


- The researchers believe that the introduction of components of net profit interim, namely operating profit, other income and other expenses, up to net profit, and this accounting detail is a qualitative addition added to the quality of the progress reports, which are integrated based on visual representation models and achieve the following advantages:

A- Additional detail of net income information enables the user of the information, especially investors, to arrive at an accurate performance assessment of the management's ability to optimize the utilization of the unit's resources, allowing the investor to evaluate the current investment and future opportunities.

B- Gives very important indicators to creditors, especially since the net profit figures, detention and distribution ratios and cash liquidity are key indicators for the granting of financial credit and appropriate financing according to the outcome of the economic unit's work and the continuity in achieving profits, especially operating profit figures.

This appropriate information is more appropriate when combined with the characteristics of colors and distinct shapes to make it more influential by the decision user, so the researchers adopted the following form:

Figure (2) 3D series to illustrate a comparison between operating profit and net profit

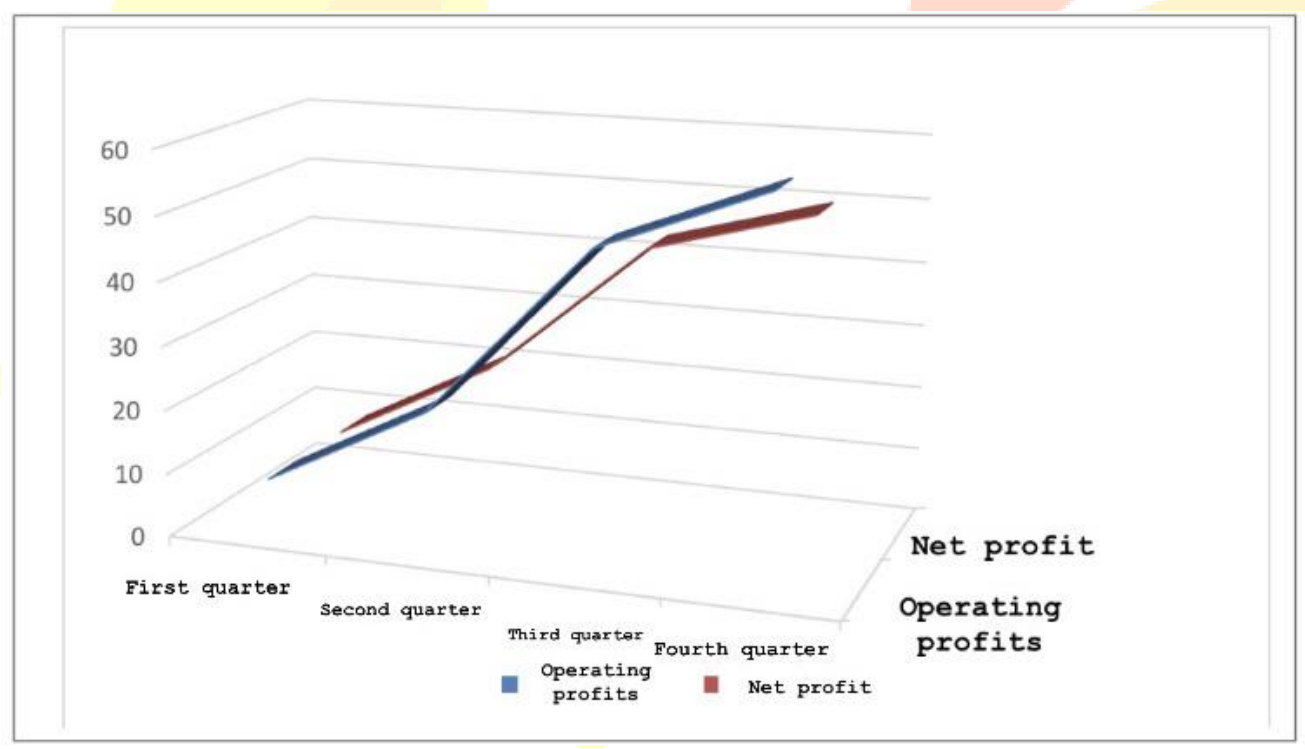


Form (3) (simple series) depicts the movement of property rights and the closing price of the company's shares

\begin{tabular}{|r|r|r|r|r|}
\hline Fourth quarter & -Third quarter & Second & -First quarter & Details \\
$2019-$ & 2019 & 2019 -quarter & 2019 & \\
\hline $383,683,029$ & $376,065,660$ & $338.506,206$ & $341,394,561$ & Value of property \\
& & & & rights \\
\hline 3,29 & 3.36 & 3,34 & 2,80 & Closing price per \\
& & & & share \\
\hline
\end{tabular}

The researchers try to show the effect of time series models according to the following:

1- The time models accurately illustrate the package relationship between the market value of the stock and the value of the property rights and this relationship visually depicts the value of the economic unit which is the value synonymous with market value, allowing the user of information in the ability to distinguish between investment and credit opportunities available and compare it with the cost of opportunity.

2- The appropriate information provided by the progress reports regarding the value of property rights and at interim periods provides a clear and complete picture of the economic unit's ability to exploit its resources to allow for reduced capital costs received and to satisfy the wishes of investors and creditors to obtain the expected returns and benefits, which are the main components of calculating the market value of the unit's shares and thus the total value of the economic unit.

3- The researchers believe that the above two forms provide a great service to all categories of users, because through the use of shapes, lines and gradients in color the user can identify the movement of property rights by increasing, stability and decrease, thus giving a clear and honest picture of the value of economic novelty from the point of view of owners, investors and creditors to support the process of drafting operational and strategic decisions based on the interactive data mentioned. 


\section{VOLUME: 12, ISSUE: 1, JANUARY-MARCH 2022}

Fifth: XBRL requirements in baghdad soft drinks company reports.

The language of financial reporting is one of the most important means of visual representation that specializes in accounting information, it works to communicate a clear and focused picture of the outcome of the economic unit's activity and financial position through a set of language dictionaries and accounting reforms that result in a range of financial and nonfinancial indicators and illustrations, as well as a variety of statistics that enhance understanding and enhance the quality of financial reports and present the researchers a set of indicators and forms provided by $\mathrm{XBRL}$ as visual representation of accounting information. :

1- Liquidity indicators: The following table shows the ratio of liquidity compared to four interim periods

Which measures the ratio of current assets to current liabilities and thus represents visible:

Table (4) Liquidity Ratio of Baghdad Soft Drinks Company

\begin{tabular}{|r|r|r|r|r|}
\hline Fourth quarter & -Third quarter & Second & -First quarter & Details \\
$2019-$ & 2019 & 2019 -quarter & 2019 & \\
\hline $6 \%$ & $3.5 \%$ & $5 \%$ & $14 \%$ & Trading ratio \\
\hline
\end{tabular}

This form provides an indication of the liquidity of the economic unit and its ability to meet its short-term commitment, and these indicators are sensitively important to creditors as they are the most risky to lose the opportunity to recover their money, especially since the liquidity ratios of the company sample the research.

1- Indicators of indebtedness: These indicators indicate the ability of the economic unit in continuity and the ability to finance its current and future projects and its successful plan for the financing structure and successful policy in diversifying the sources of financing as well as give high risk indicators and table (5) shows the debt ratios for the four interim periods, which are reached by measuring the ratio of total liabilities to total assets during 2019: 
VOLUME: 12, ISSUE: 1, JANUARY-MARCH 2022

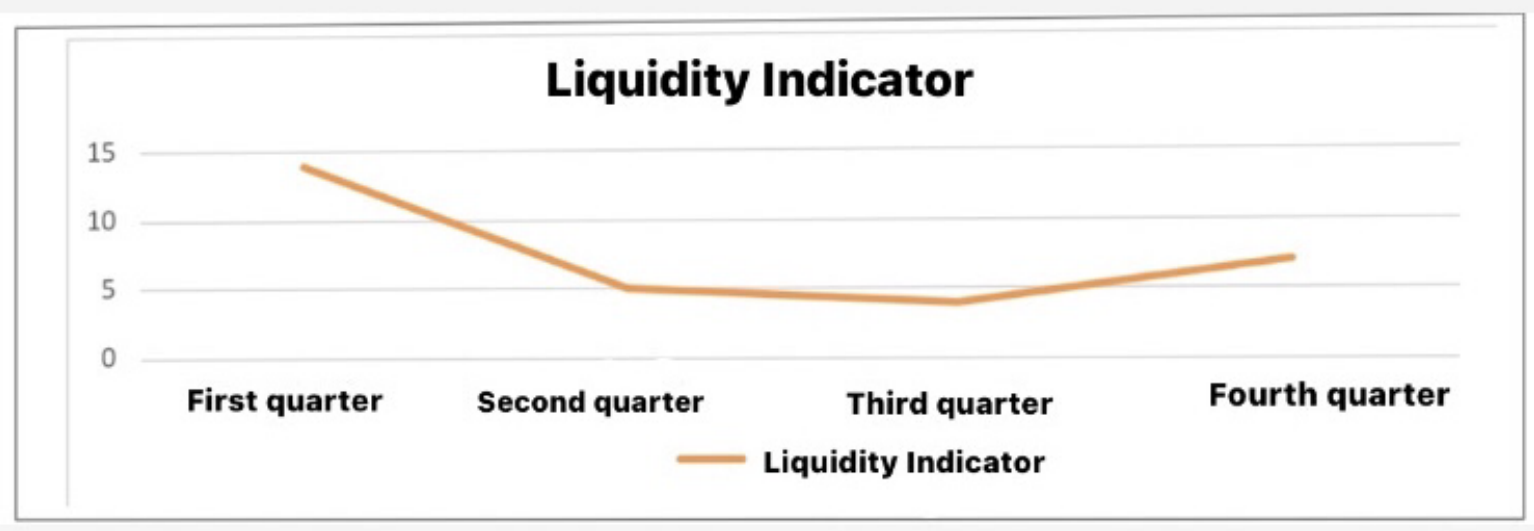

Table 5 shows the debt ratios of Baghdad Soft Drinks Company

\begin{tabular}{|r|r|r|r|r|r|}
\hline Fourth quarter & -Third quarter & Second & -First quarter & Details \\
$2019-$ & 2019 & 2019 -quarter & 2019 & \\
\hline $8 \%$ & $13 \%$ & $7 \%$ & $2.64 \%$ & Debt ratio \\
\hline
\end{tabular}

Figure 5 shows a three-dimensional time series of debt indicators for Baghdad Soft Drinks

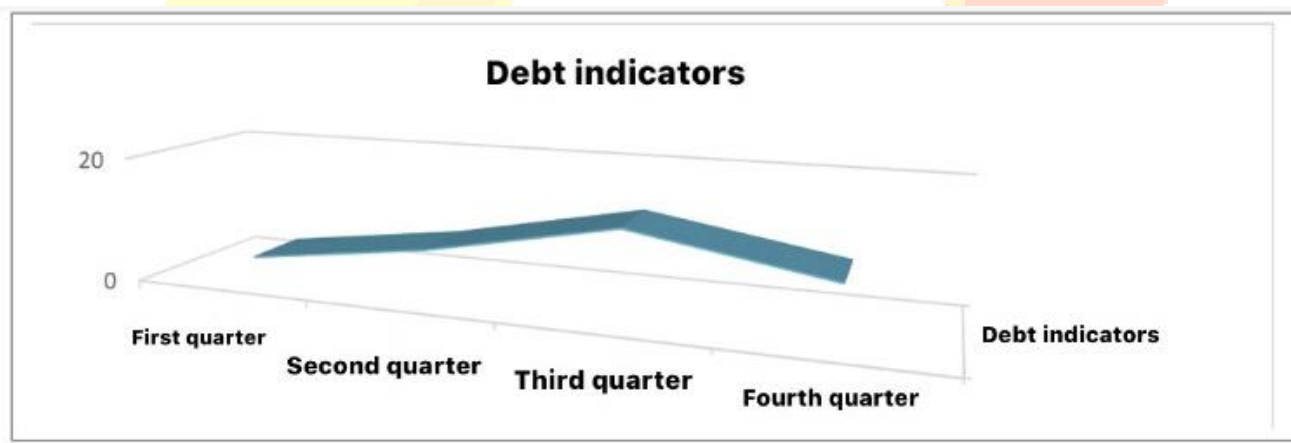




\section{COMPANY}

- Profitability ratios: These ratios measure the unit's ability to generate profits and reach optimal use of resources and measure this ratio by measuring the ratio of net income to total assets to determine the ability of assets to produce revenues, maximize profits and measure the ratio of net income to equity to see the amount of return on property rights and the ability of management to generate revenue, exploit capital and table (6) illustrates these indicators. :

Table (6) profitability indicators for the four interim periods of the company research sample

\begin{tabular}{|r|r|r|r|r|}
\hline Fourth quarter & -Third quarter & Second & -First quarter & Details \\
$2019-$ & 2019 & 2019 -quarter & 2019 & \\
\hline $12 \%$ & $9 \%$ & $6 \%$ & $-2.36 \%$ & Return on assets \\
\hline $13 \%$ & $12 \%$ & $6,25 \%$ & $-2,43$ & Return on equity \\
\hline
\end{tabular}

Figure (6) Simple columns comparing return on ownership and return on capital

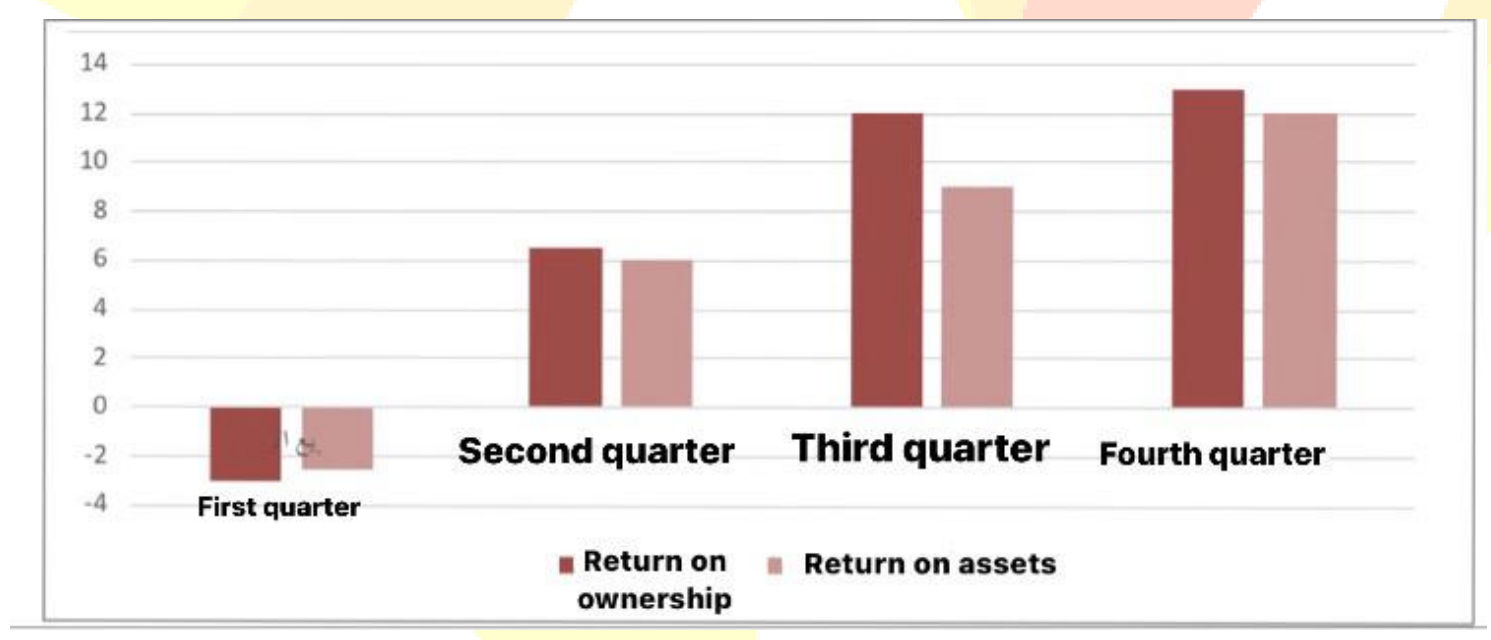

Visual representation in Figure 6 notes how visual representation affects the visual image and the ability to influence the visual sensors of the information user, especially investors who sense the relative importance of these indicators and the appropriateness of this visual representation, which demonstrates the ability of the unit to exploit its resources and generate profits over the four stages of the progress reports, thereby enhancing the 


\section{VOLUME: 12, ISSUE: 1, JANUARY-MARCH 2022}

appropriateness and credibility of the information of those reports.

\section{CONCLUSIONS:}

1. Progress reports represent an advanced entry into the financial reporting function as they provide appropriate reporting requirements and honest representation, especially when they meet the requirements of the International Financial Reporting Standards and focus on the appropriate timing to present the information needed by the stakeholders.

2. Compliance with the requirements of international financial reporting standards, especially as they are applicable at the beginning of the year 2021 through improving information systems and displaying financial reports.

3. Enhancing the efforts of professional organizations to continuously strive towards reaching the interim financial reporting function to the level of reports with adequate and appropriate disclosure that enhance the decisions of users.

4. The means of visual representation are successful tools to address the visual sensors, which enhances the ability to understand the information.

5. The integration between the advantages of interim financial reporting and the advantages of visual representation of information improves the quality of financial reporting and reduces the expectations gap.

\section{RECOMMENDATIONS:}

1. The management of the economic unit should focus on visual representation methods, as they are successful tools to convey a clear picture of indicators, figures and financial ratios that are inputs to users' decisions.

2. Directing the bodies responsible for managing the Iraq Stock Exchange to include requirements for visual representation of information as part of the companies' listing requirements.

3. Developing accountants 'technical and technological capabilities to develop and improve information systems in line with labor market requirements and users' desires.

4. The introduction of visual representation methods in accounting education curricula to enable graduates to acquire skills and technologies that help them perform their job efficiently and effectively.

5. Focusing on the importance of integration between progressive reporting and information visualization technology, as it is one of the episodes of financial reporting development. 


\section{REFERENCES}

1-Al-Khatib, Khaled, "International Standards for Financial Reporting" was prepared as part of the scientific activities of the Securities and Exchange Commission in cooperation with the Association of Syrian Chartered Accountants and the Faculty of Economics, Damascus University, Syria, November 2009.

2-Aulia-Absari Khalil, A. R., Junaedi, P. A., \& Kanigoro, B. (2015). Data visualization application for analyzing public company financial statement. Procedia Computer Science, 59, 45-53.

3-Cvek, U., Trutschl, M., Stone, R., Syed, Z., Cvek, J. L., \& Sabichi, A. L. (2009). Multidimensional visualization tools for analysis of expression data. World Academy of Science, Engineering and Technology, 54(50), 281-289.

4-Dilla, W., Janvrin, D. J., \& Raschke, R. (2010). Interactive data visualization: New directions for accounting information systems research. Journal of Information Systems, 24(2), 1-37.

5-Dull, R. B., \& Tegarden, D. P. (1999). A comparison of three visual representations of complex multidimensional accounting information. Journal of Information Systems, 13(2), 117-131.

6-Few, S. (2006). Visual communication: Core design principles for displaying quantitative information. Perceptual Edge, Cognos Innovation Center.

7-Hamad, Tarek Abdel Aal, Financial Reports, University House, Alexandria, Egypt, 2006.

8-Havre, S., Hetzler, E., Whitney, P., \& Nowell, L. (2002). Themeriver: Visualizing thematic changes in large document collections. IEEE transactions on visualization and computer graphics, 8(1), 9-20.

9-International Accounting Standards Board. (2006). International Financial Reporting Standards (IFRS's): Including International Accounting Standards (IAS's) and Interpretations as at... International Accounting Standards Board.

10-Merhi, Abdul Rahman, the role of accounting information provided by the progress reports in making investment decisions - Applied Study, Damascus University Journal of Economic and Legal Sciences, Volume 22, Issue II. 2006. 


\section{VOLUME: 12, ISSUE: 1, JANUARY-MARCH 2022}

11-Perdana, A., Robb, A., \& Rohde, F. (2019). Interactive data visualisation for accounting information: a three-fit perspective. Behaviour \& Information Technology, 38(1), 85-100.

12-Perkhofer, L. M., Hofer, P., Walchshofer, C., Plank, T., \& Jetter, H. C. (2019). Interactive visualization of big data in the field of accounting. Journal of Applied Accounting Research.

13-Qin, X., Luo, Y., Tang, N., \& Li, G. (2020). Making data visualization more efficient and effective: A survey. The VLDB Journal, 29(1), 93-117.

14-Sackett, P. J., Al-Gaylani, M. F., Tiwari, A., \& Williams, D. (2006). A review of data visualization: opportunities in manufacturing sequence management. International Journal of Computer Integrated Manufacturing, 19(7), 689-704.

15-Shneiderman, B. (1992). Tree visualization with tree-maps: 2-d space-filling approach. $A C M$ Transactions on graphics (TOG), 11(1), 92-99.

16-Skek, Tarek Fayez, impact of interim financial reports on the share price and volume of trading - applied study on companies listed on the Palestine Stock Exchange, Master's thesis

17-Tegarden, D. P. (1999). Business information visualization. Communications of the Association for Information Systems, 1(1), 4.

18-Ware, C. (2019). Information visualization: perception for design. Morgan Kaufmann. 